\title{
Recent surging event of a glacier on Geladandong Peak on the Central Tibetan Plateau
}

\section{Letter}

Cite this article: $\mathrm{Xu} \mathrm{J}$, Shangguan $\mathrm{D}$, Wang $\mathrm{J}$ (2021). Recent surging event of a glacier on Geladandong Peak on the Central Tibetan Plateau. Journal of Glaciology 67(265), 967-973. https://doi.org/10.1017/jog.2021.86

Received: 2 December 2020

Revised: 27 June 2021

Accepted: 28 June 2021

First published online: 27 July 2021

\section{Key words:}

Geladandong Peak; glacier surging; surface velocity changes

Author for correspondence:

Junli Xu, E-mail: xujunli@lzb.ac.cn (c) The Author(s), 2021. Published by Cambridge University Press. This is an Open Access article, distributed under the terms of the Creative Commons Attribution-

NonCommercial-NoDerivatives licence (http:// creativecommons.org/licenses/by-nc-nd/4.0/), which permits non-commercial re-use,

distribution, and reproduction in any medium, provided the original work is unaltered and is properly cited. The written permission of Cambridge University Press must be obtained for commercial re-use or in order to create a derivative work.
Junli $\mathrm{Xu}^{1}$ (D), Donghui Shangguan ${ }^{2}$ (i) and Jian Wang ${ }^{1}$ (D)

${ }^{1}$ College of Urban and Environmental Sciences, Yancheng Teachers University, Yancheng 224002, China and ${ }^{2}$ State Key Laboratory of Cryospheric Sciences (SKLCS), Northwest Institute of Eco-Environment and Resources, Chinese Academy of Sciences, Lanzhou 730000, China

\begin{abstract}
Few surges on the Central Tibetan Plateau have been reported. Here, we report observations of a recent surging event of the Gangjiaquba Glacier in the Geladandong Peak region using surface velocity and morphology changes that were extracted from Landsat MSS/TM/ETM+/OLI images obtained from 1973 to 2019. The results reveal that the active surge of this glacier initiated at the end of summer in 2014 and terminated in 2016. The surge resulted in a total advance of $500 \pm$ $11.2 \mathrm{~m}$ and many fresh crevasses in the surging zone. The maximum velocity was $1100 \mathrm{~m} \mathrm{a}^{-1}$ during the active surge phase, which is much smaller than those observed in Karakoram but similar to observations in West Kunlun.
\end{abstract}

\section{Introduction}

Surge-type glaciers account for only $\sim 1 \%$ of all global glaciers, but they tend to cluster in a few regions (Sevestre and Benn, 2015). Usually, dozens of such glaciers develop in the same arctic or alpine region (Benn and Evans, 2010). This brings the challenge to reconstruct or forecast glaciers response to climate change (Yde and Paasche, 2010).

Two well-known theories about the trigger mechanism of surging have been formed based on field observations: hydrological control and thermal control (Kamb and others, 1985; Clarke and others, 1986; Murray and others, 2003). Hydrologically controlled surges are typical for glaciers in Alaska (Kamb, 1987), while a thermally controlled meltwater mechanism might explain some surges in Svalbard (Fowler and others, 2001; Murray and others, 2003). However, a recent theory for surging behaviour includes both temperate and polythermal glacier surges and is based on coupled mass and enthalpy budgets (Sevestre and Benn, 2015; Benn and others, 2019). However, the mechanism of surges in most regions are still ambiguous, especially that of glacier surges in areas of the Tibetan Plateau, like the Karakoram Mountains, Muztag Peak in Pamir and West Kunlun Mountains (Paul, 2020).

There is especially limited knowledge about how glaciers surge on the central Tibetan Plateau. Only tens of surge-type glaciers in West Kunlun and Central Kunlun have information available about the surface velocity changes of the surging phase (Yasuda and Furuya, 2015; Chudley and Willis, 2018; Fu and others, 2019; Gao and others, 2021; King and others, 2021). There may even be more surge-type glaciers that have not been reported. Wei and others (2014) concluded that $\sim 890(1.5 \%)$ potential surge-type glaciers were located in the interior area of the Tibetan Plateau during the period of 1970-2009. Thus, more observations on the surging glaciers on the Tibetan Plateau are required.

Geladandong Peak in the Central Tibetan Plateau is the highest mountain in the source region of the Yangtze River (Figs 1a, b). There were 19 surge-type glaciers identified based on elevation and velocity changes analysis (Yan and others, 2019; Gao and others, 2021; King and others, 2021).

Gangjiaquba Glacier $\left(33.46^{\circ} \mathrm{N}, 91.17^{\circ} \mathrm{E}\right.$, GLIMS ID G091171E33460N) originates from Geladandong Peak (Figs 1b, c). In 1968, it covered an area of $37.44 \pm 1 \mathrm{~km}^{2}$, had an average thickness of $146 \pm 3 \mathrm{~m}$ and descended across a large altitudinal range of $6621-5300 \mathrm{~m}$ a.s.l. $(\mathrm{Pu}, 1994)$. There is a long medial moraine between tributaries 2 and 3 but the glacier is almost devoid of debris except for this medial moraine. Gangjiaquba Glacier was reported as the largest shrinkage in area and recession in length of all glaciers in Geladandong region, with five main tributaries reducing to four tributaries between 1973 and 2013 (Xu and others, 2018), and was identified as a surge-type glacier by King and others (2021). However, change of morphology (geometry, crevasses) and detailed change of velocity during the active surge phase, and velocities over the quiescent phase, which was not shown in previous study (King and others, 2021), are important parameters for the glacier surge model (Benn and others, 2019). Here changes in surface velocity, surface elevation, tongue area and the medial moraine are employed to recognize how the surge build up over the quiescent phase and how the glacier surges and terminates.

\section{Datasets and methods}

Thirty-nine Landsat 1 MSS, 5 TM, 7 ETM+ and 8 OLI images from 1973 to 2019, offered by the United States Geological Survey (USGS, http://earthexplorer.usgs.gov/), were used in this 


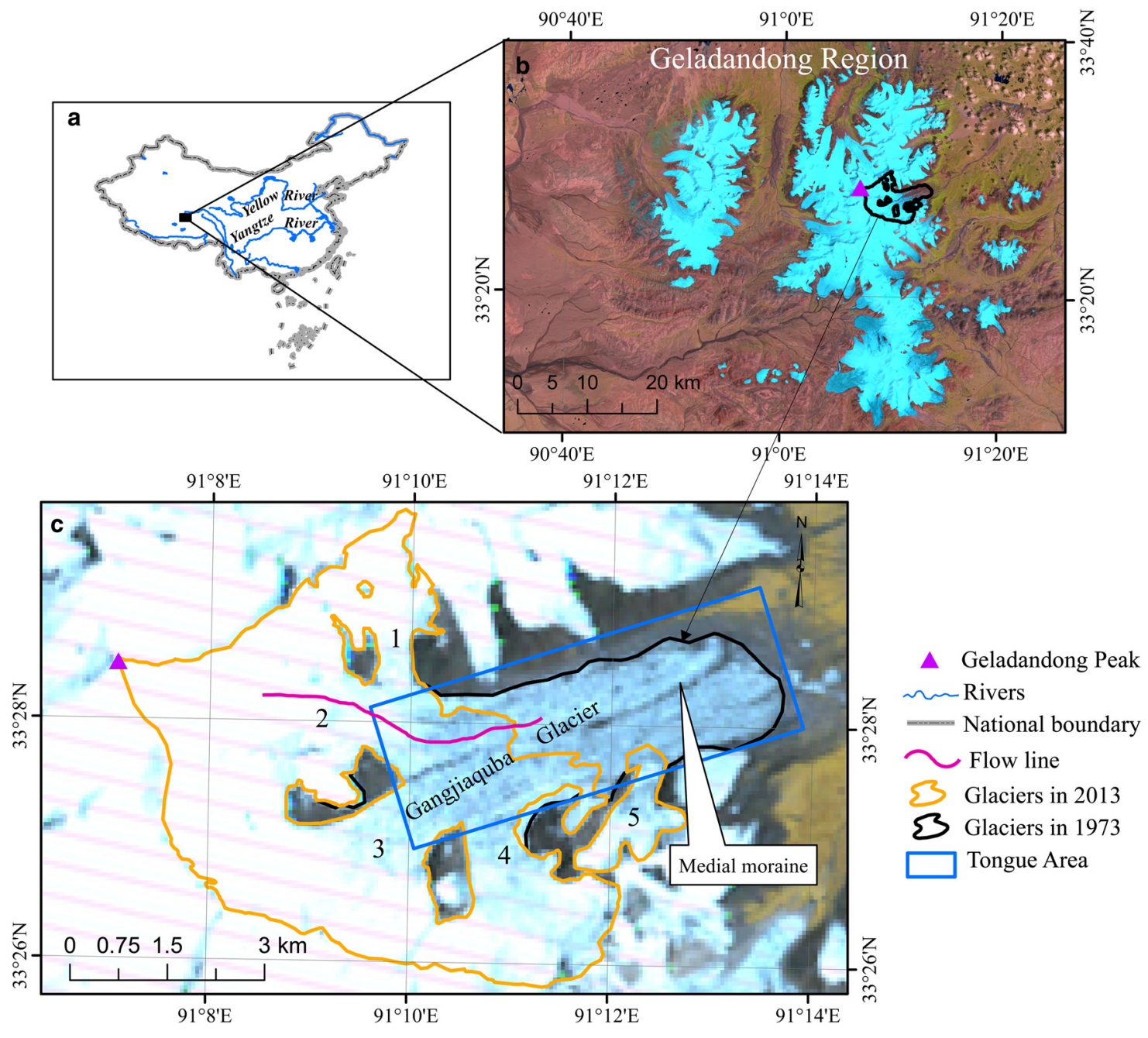

Fig. 1. Location of the Geladandong region and the Gangjiaquba Glacier. (a) The location of Geladandong region, (b) the location of the glacier (background is the Landsat TM of 8 November 2008), and (c) the Gangjiaquba Glacier on the Landsat MSS of 16 July 1973. The tributaries are numbered 1-5. The glacier boundaries in 1973 and 2013 were obtained from Xu and others (2018).

study (Table S1). Velocities were extracted by employing the COSI-CORR (Co-registration of Optically Sensed Images and Correlation) software (Leprince and others, 2007; Scherler and others, 2008), which has been proven to be effective for displacement measurement using Landsat images (Pitte and others, 2016; Paul and others, 2017; Chudley and Willis, 2018; Liu and others, 2020). We set the initial search window and the final window to 32 and 16 pixels for TM band 3 (64 and 16 pixels for OLI band 8), which is a compromise between the image pixel size and the expected displacement of the glacier surface. The threshold of the signal-to-noise ratio was set to 0.95 and the step size of 2 pixels for TM (4 for OLI) was set for velocity interpolation with $60 \mathrm{~m}$ resolution. The influence of cloud and shadow was removed by the low-pass filter, and the anomalous flow direction of vectors was removed manually (Fu and others, 2019). The displacement was scaled to velocity with units of $\mathrm{m} \mathrm{a}^{-1}$. Seventeen phases of velocity were calculated based on 18 images (Table S2).

The glaciomorphological change of glacier tongue area, medial moraine, supraglacial lakes and crevasses were assessed by the terminus evolution (Fig. 1). Six glacier-tongue-area binary images of Landsat TM/OLI (30 July 1986, 31 August 1992, 17 September 1998, 1 September 2004, 1 August 2010, 2 October 2015) were generated through the segmentation of the band ratio image TM 3/TM 5 (for Landsat 8 image OLI 4/OLI 6) by a threshold of 2.1-2.4 (Table S1). A binary classification image of glacier tongue area from MSS (16 July 1973) was generated by the minimum-distance supervised classification into ice and ice-free areas, implementing in ENVI/IDL 5.3 software using the composite image of bands 7, 6 and 5 after resampling to $30 \mathrm{~m} \times 30 \mathrm{~m}$ resolution. Glacier tongue area changes between images were classified as 1 for expansion (non-glacier changing to glacier), 0 for no change and -1 for shrinkage by post-event binary image minus previous one. In addition, the annual medial moraine was digitized to figure out the changes of tributaries based on 36 images. The position of medial moraine relative to 1973 was calculated using the average of seven points on the change direction (Fig. S1). For supraglacial lake and crevasse changes, we classified only whether the features existed at each time period, and did not calculate their area.

Glacier surface elevation changes were used to confirm the surge through the downstream transfer of ice which is proven to be a characteristic of the surge event (Grant and others, 2009; Sund and others, 2009). Three multitemporal digital elevation models (DEMs) from topographic maps of 1968 based on aerial photography (DEM1968), shuttle radar topography mission (SRTM) in band C from 2000, and SPOT 6/7 stereo image pairs from 6 October 2013 and 18 November 2014 (DEM2014) were provided by Xu and others (2018) for the elevation difference analysis. The penetration in snow and ice of SRTM C has been corrected using SRTM X. The error due to the co-registration and coarse resolution was removed using the method of Gardelle and others (2012). The difference between SRTM and 

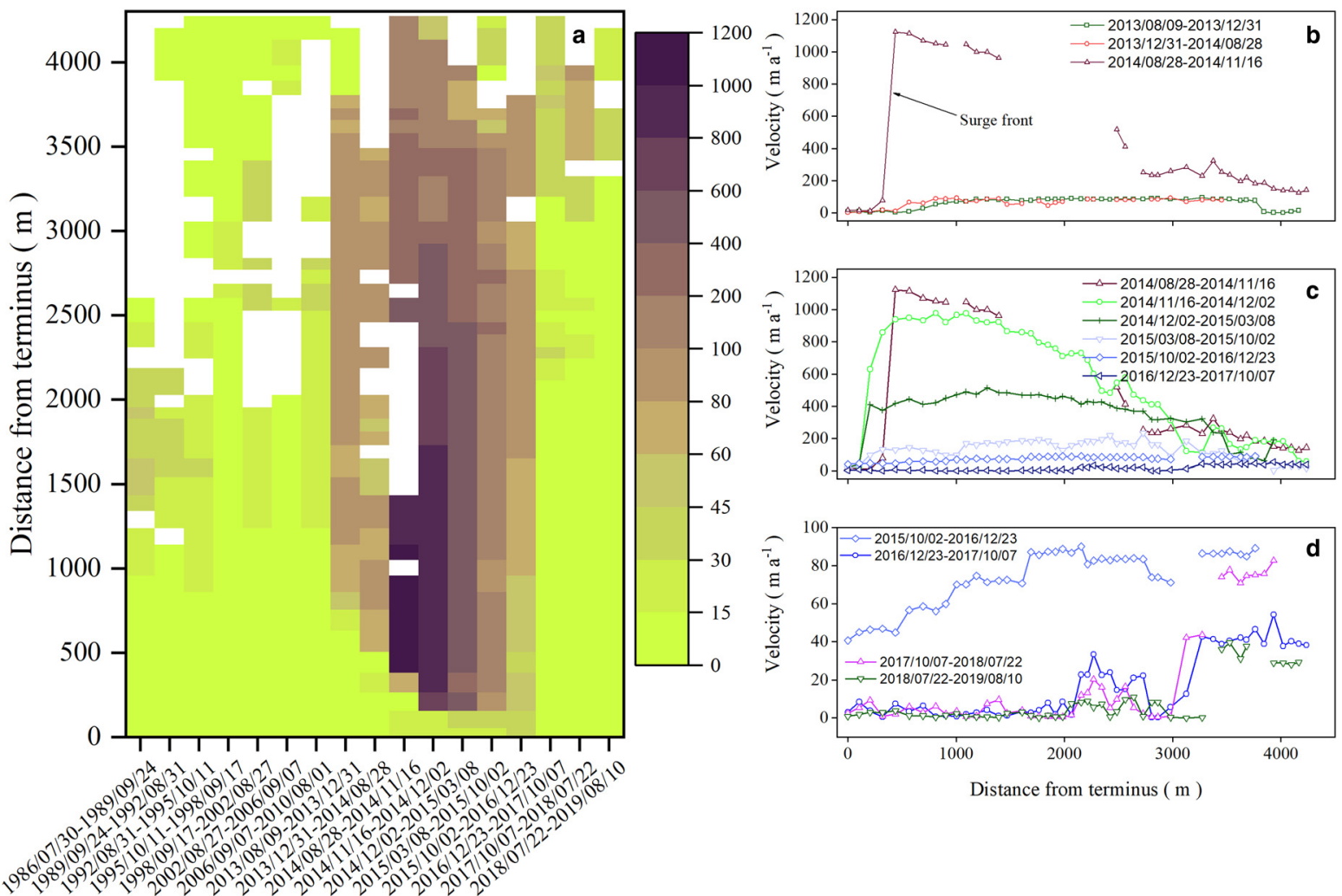

Fig. 2. Evolution of flow velocities from 1986 to 2019 along the flowline in Figure S3. (a) The Hovmöller plot, (b) velocity from 9 August 2013 to 16 November 2014 (the surge build up to the maximum), (c) 16 November 2014 to 23 December 2016 (the surge weakening until exhausted), and (d) 23 December 2016 to 10 August 2019 (after the surge).
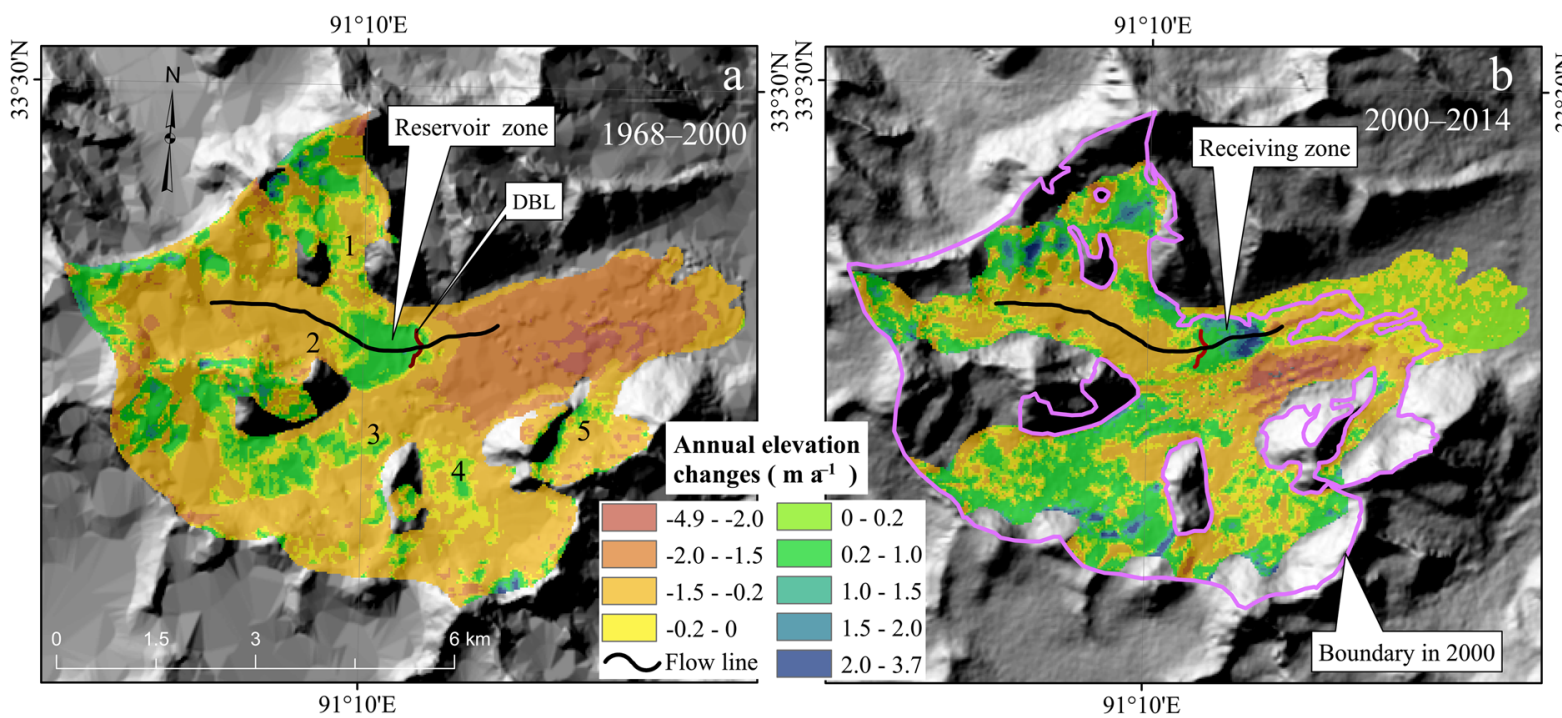

Fig. 3. Surface elevation changes of the glacier from 1968 to 2014 masked by the glacier boundary from 1973. (a) Changes between 1968 and 2000 (DBL: dynamic balance line) and (b) changes between 2000 and 2014 (shadow area removed, purple line is the glacier boundary in 2000).

DEM1968 (DEM2014) off glacier area shown in Figure S2 was assessed as $0.36 \pm 8.95 \mathrm{~m}(-0.05 \pm 3.92 \mathrm{~m}$, mean \pm std dev. $)$.

\section{Results}

In the first cloud-free Landsat MSS from 1973, Gangjiaquba Glacier covers an area of $36.56 \pm 1.13 \mathrm{~km}^{2}$, has a length of $10.0 \mathrm{~km}$ and a tongue with a width of $1.8 \mathrm{~km}$. Seventeen velocity fields generated between 1986 and 2019 indicate three stages to the evolution of the surge (Fig. S3). Changes along the profile of the median flowline are shown in Figure 2. From 1986 to 2010, the velocity across much of the glacier area was $<5 \mathrm{~m} \mathrm{a}^{-1}$, except for tributary 2 at the junction towards 3 (Figs S3a-g). Here, the velocity was $30-45 \mathrm{~m} \mathrm{a}^{-1}$ from 1986 to 1995 , and fell below $5 \mathrm{~m} \mathrm{a}^{-1}$ after 1995. Between 2006 and 2010 , the velocity rose to $30 \mathrm{~m} \mathrm{a}^{-1}$. In this stage, the mean glacier velocity was $<5 \mathrm{~m} \mathrm{a}^{-1}$ and changed little annually.

The second stage was from 2013 to 2016, and was marked by a significant increase of motion over the ablation areas of tributaries 1 and 2, indicative of a surge during this period (Figs S3h-n). Between 9 August 2013 and 28 August 2014, the velocity 

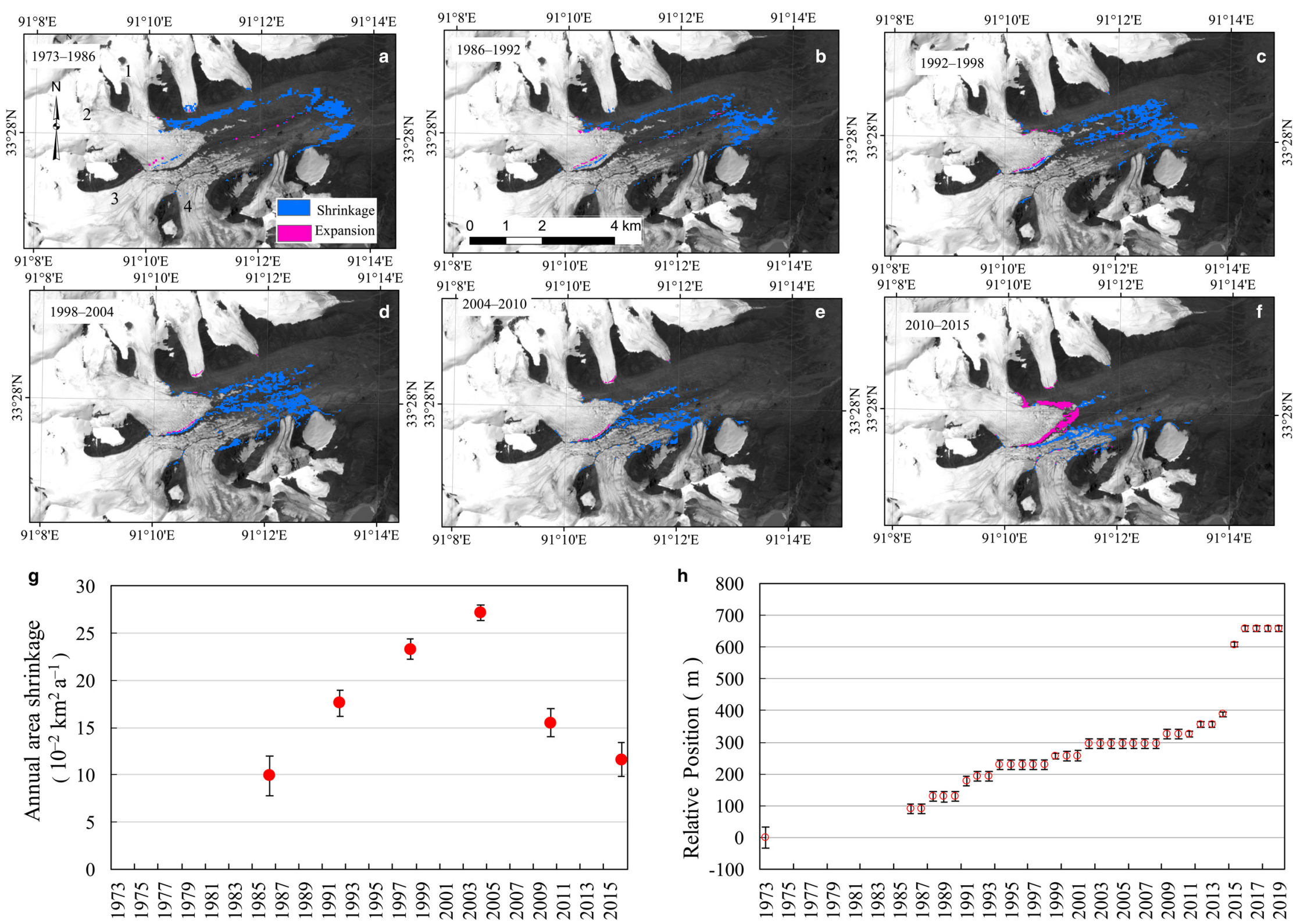

Fig. 4. Changes of glacier tongue from 1973 to 2019. (a-f) The area change over 1973-1986, 1986-1992, 1992-1998, 1992-2004, 2004-2010, 2010-2015, the background is the panchromatic band of Landsat 8 OLI from 2013/08/09; (g) the annual shrinkage area from during these periods; and (h) the position relative to 1973. 

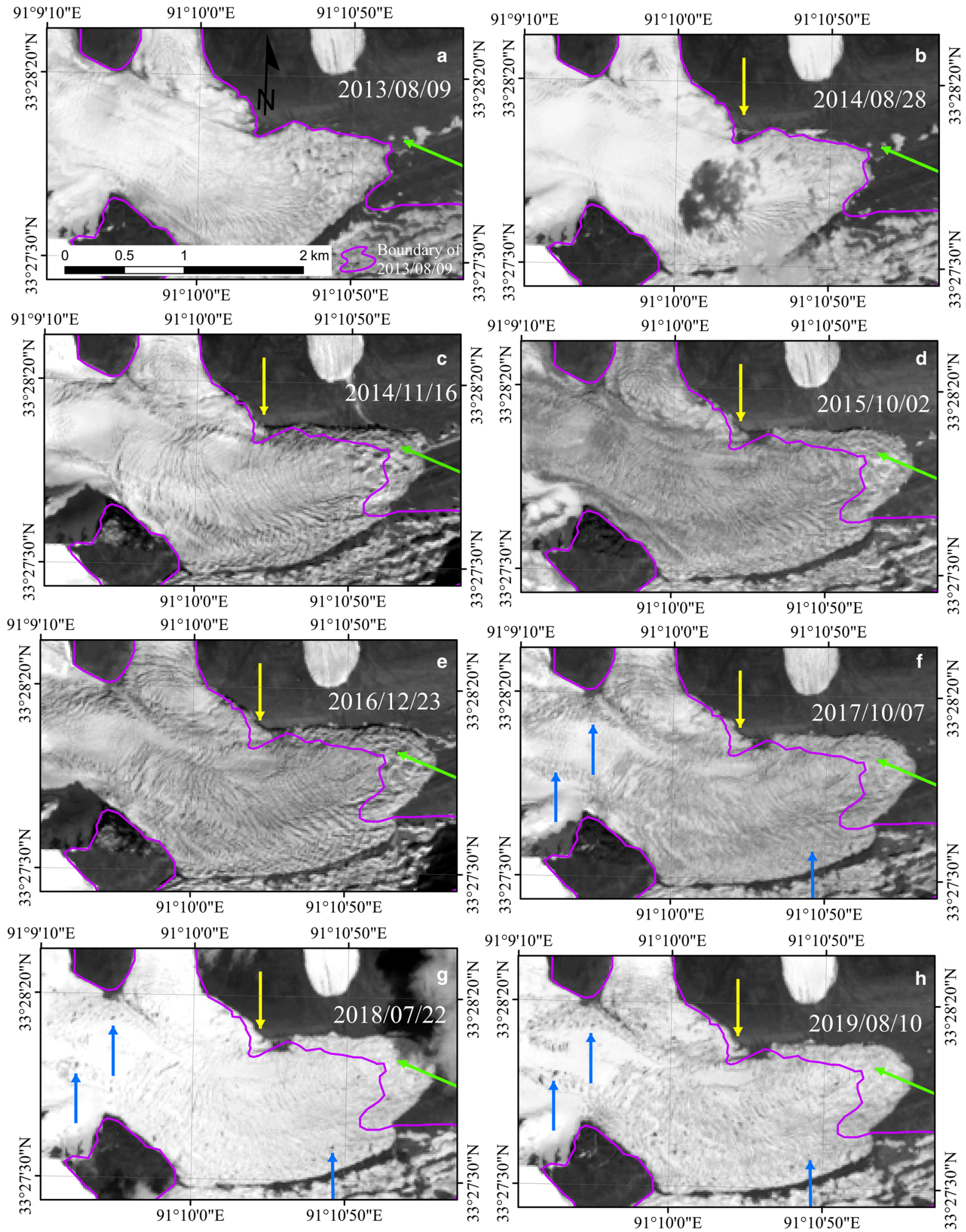

Fig. 5. Surface changes of Gangjiaquba Glacier from 2013 to 2019. The yellow arrows show the changes at the terminus of tributary 1 , the green arrows show the changes at the terminus of tributary 2 , and the blue arrows show supraglacial lakes that formed after surging. Here arrows do not change with images.

increased to $45-86 \mathrm{~m} \mathrm{a}^{-1}$ over the ablation area of tributary 2 and propagated down to the terminus with the same speed (Figs S3hi), while the surge built up. The maximum motion of $1100 \mathrm{~m} \mathrm{a}^{-1}$ $\left(3.0 \mathrm{~m} \mathrm{~d}^{-1}\right)$ occurred over 28 August to 16 December 2014, following the surge initiation (Figs 2a, b). A surge front, which was described as a kinematic wave (Kamb and others, 1985), accompanied this strongest acceleration of the glacier. After this peak movement, the surge front advanced and weakened continuously (Fig. S3c). The front disappeared between 2 October 2015 and 23 December 2016 with velocity decreasing to $45-85 \mathrm{~m} \mathrm{a}^{-1}$, similar to the pre-surge velocity. Although tributary 1 was also observed to surge, it had a much lower maximum velocity than tributary 2 during this surging phase (Figs $\mathrm{S} 3 \mathrm{~h}-\mathrm{j}$ ). The maximum speed of tributary 1 was $\sim 150 \mathrm{~m} \mathrm{a}^{-1}$, which occurred between 16 November 2014 and 8 March 2015, 3 months later than in tributary 2.

After 23 December 2016, the velocity decreased to $<5 \mathrm{~m} \mathrm{a}^{-1}$, and the surge terminated (Fig. 2d). Meanwhile, the velocity 
upstream of tributary 2 increased to $60 \mathrm{~m} \mathrm{a}^{-1}$, indicative of a potential subsequent phase of surging.

Change maps with a resolution of $30 \mathrm{~m}$ on the glacier surface elevation from 1968 to 2014 are visualised in Figure 3. These indicate a reduction in elevation of the tongue area at a rate of $2.0 \pm$ $1.1 \mathrm{~m} \mathrm{a}^{-1}$ from 1968 to 2000 , alongside an area of thickening on the junction of tributary 2 towards 3 at a rate of $0.35 \pm 0.16 \mathrm{~m}$ $\mathrm{a}^{-1}$ (Fig. 3a). This $1.5 \mathrm{~km}$-long thickening zone $\left(1.1 \pm 0.4 \mathrm{~km}^{2}\right.$ with $1.3 \pm 0.2 \times 10^{7} \mathrm{~m}^{3}$ ice volume) is likely the reservoir zone. From 2000 to 2014, ice transferred towards the snout from the reservoir zone (Fig. 3b). A dynamic balance line was identified, which had no elevation change when ice transferred to the receiving zone, and was observed on many glaciers (Raymond and others, 1987; Kochtitzky and others, 2019). Continuous thickening in the upstream of tributary 3 and thinning in the lower part from 1968 to 2014 steepened this tributary.

The glacier tongue covered an area of $10.7 \pm 2.1 \mathrm{~km}^{2}$ in 1973 . The glacier tongue area experienced expansion and shrinkage at the same time in different zones from 1973 to 2015 (Figs 4a-f). The shrinkage occurred in the lower part of the tongue at heterogeneous speed temporally. The shrinkage rate of area increased from $0.1 \pm 0.02$ to $0.27 \pm 0.08 \mathrm{~km}^{2} \mathrm{a}^{-1}$ from 1973 to 2004 , and then slowed down (Fig. 4g). Meanwhile, expansion was observed at the junction of tributaries 2 towards the 3 over the observation period, and the front of tributary 1 from 2010 to 2015 (Fig. 4h). In combination with the surface velocity and elevation changes, it is likely that the ice being received from tributary 2 displaced tributary 3 and thus the medial moraine between them. It moved southeastwards by $356 \pm 11.4 \mathrm{~m}\left(9.1 \pm 0.3 \mathrm{~m} \mathrm{a}^{-1}\right)$ from 1973 to 2012, and $302 \pm 11.3 \mathrm{~m}$ from 2012 to 2016 (Fig. S1 and Fig. 4h).

Changes of crevasses and supraglacial lakes on the terminus from 2013 to 2019 are shown in Figure 5. From 9 August 2013 to 28 August 2014, an advance of $50 \pm 11.3 \mathrm{~m}$ without an area of fresh crevasses was observed. During the active surging phase (28 August 2014 to 23 December 2016), many fresh transverse crevasses emerged on the surging zone (Fig. 5c). However, the surge bulge was not visible on Gangjiaquba glacier on Landsat images during the observed period, which was clear on some surge-type glaciers during the active surge phase (Murray and others, 1998; Jiskoot and Juhlin, 2009). This surge also resulted in a total advance of $500 \pm 11.2 \mathrm{~m}$ by tributary 2 (Fig. 5, green arrows), and of $180 \pm 11.2 \mathrm{~m}$ by tributary 1 (Fig. 5 , yellow arrows).

After the surge, an increase in supraglacial meltwater in ponds and crevasses was observed over the surged zone (Fig. 5, blue arrows). Soon after the surge (23 December 2016 to 10 August 2019), a recession of tributary 1 occurred, but not of tributary 2 .

\section{Discussion and conclusion}

A complete surging process of Gangjiaquba Glacier was observed through changes of velocity, terminus morphology and elevation changes. Surging initiated in the summer of 2013, was active from the end of summer in 2014-2016, and was depleted after 2016. The surging lasted for $\sim 3$ years, resulting in the terminus advancing by $500 \pm 11.2 \mathrm{~m}$, pushing the medial moraine southeastwards $302 \pm 11.3 \mathrm{~m}$. The maximum velocity occurred between 28 August and 2 December 2014 , and was $1100 \mathrm{~m} \mathrm{a}^{-1}\left(3 \mathrm{~m} \mathrm{~d}^{-1}\right)$. It has comparable maximum velocity and similar surging duration with its two adjacent surge-type glaciers (G091091E33424N and G091071E33463N) (Yan and others, 2019), which have a similar area as Gangjiaquba $\left(27.03 \pm 0.83\right.$ and $\left.34.92 \pm 1.08 \mathrm{~km}^{2}\right)(\mathrm{Xu}$ and others, 2018). The maximum velocity observed in our study is about seven times as that observed by King and others (2021). It is the longer observation period by King and others (2021) that reduce the velocity value. Correspondingly, the maximum velocity of other surge-type glaciers $\left(<100 \mathrm{~m} \mathrm{a}^{-1}\right)$ in Geladandong region was also much smaller than that of Gangjiaquba (Gao and others, 2021; King and others, 2021).

The maximum velocity of Gangjiaquba Glacier is comparable to that of reported surging-type glaciers in the West Kunlun and Central Kunlun Mountains $\left(0.2-4.5 \mathrm{~km} \mathrm{a}^{-1}\right.$ ) (Yasuda and Furuya, 2013; Chudley and Willis, 2018; Fu and others, 2019). Although some surge-type glaciers in the West-Kunlun are smaller, they have similar terminus advance (549-1524 m) but longer surging duration (Chudley and Willis, 2018). However, the maximum velocity of Gangjiaquba is much smaller than that of the Shisper Glacier $\left(48 \mathrm{~m} \mathrm{~d}^{-1}\right)$ in the Karakoram Mountains, even in the similar size with an area of $26 \mathrm{~km}^{2}$ (Rashid and others, 2020). Gangjiaquba has a much shorter surging duration than some surge-type glaciers in Svalbard (Murray and others, 1998, 2003).

Transfer of ice from the reservoir area to the receiving area was observed through the elevation changes from 1968 to 2014. Although the reservoir zone of Gangiiaquba Glacier was not calculated over the entire quiescent phase, the location of the dynamic balance line changed little (cf. Raymond and others, 1987; Kochtitzky and others, 2019). Our observed length of reservoir zone of Gangjiaquba Glacier was much shorter than that of Sabche Glacier in Nepal, which has a much smaller area (9.1 $\mathrm{km}^{2}$ ) (Lovell and others, 2018). This might be why this surge of Gangjiaquba Glacier has a relatively low surge peak velocity.

Our results show two tributaries surged in different amplitudes during 2013 and 2016, another tributary was still in thickening of reservoir zone. This heterogeneous surging pattern across different tributaries also occurs on other glaciers (Hewitt, 2007; Shangguan and others, 2016; Paul, 2020).

Supplementary material. The supplementary material for this article can be found at https://doi.org/10.1017/jog.2021.86

Acknowledgements. This research was funded by the Key Research Program of Frontier Sciences, CAS (grant No.: XDA19070501), National Natural Science Foundation of China (grant No.: 41671075 and 41950410575).

\section{References}

Benn DI and Evans DJA (2010) Glaciers \& Glaciation, 2nd Edn. London, UK: Hodder Education.

Benn DI, Fowler AC, Hewitt I and Sevestre H (2019) A general theory of glacier surges. Journal of Glaciology 65(253), 701-716. doi: 10.1017/jog.2019.62

Chudley TR and Willis IC (2018) Glacier surges in the north-west West Kunlun Shan inferred from 1972 to 2017 Landsat imagery. Journal of Glaciology 65(249), 1-12. doi: 10.1017/jog.2018.94

Clarke GKC, Schmok JP, Ommanney CSL and Collins SG (1986) Characteristics of surge-type glaciers. Journal of Geophysical Research: Solid Earth 91(B7), 7165-7180. doi: 10.1029/JB091iB07p07165

Fowler AC, Murray T and Ng FSL (2001) Thermally controlled glacier surging. Journal of Glaciology 47(159), 527-538. doi: 10.3189/ 172756501781831792

Fu X, Li Z and Zhou J (2019) Characterizing the surge behavior of Alakesayi Glacier in the West Kunlun Shan, Northwestern Tibetan Plateau, from remote-sensing data between 2013 and 2018. Journal of Glaciology 65 (249), 168-172. doi: 10.1017/jog.2019.2

Gao Y and 6 others (2021) Characterizing the behaviour of surge-type glaciers in the Geladandong Mountain Region, Inner Tibetan Plateau, from 1986 to 2020. Geomorphology 389, 107806. doi: 10.1016/j.geomorph.2021.107806

Gardelle J, Berthier E and Arnaud Y (2012) Slight mass gain of Karakoram glaciers in the early twenty-first century. Nature Geoscience 5(5), 322-325. doi: $10.1038 /$ ngeo1450

Grant KL, Stokes CR and Evans IS (2009) Identification and characteristics of surge-type glaciers on Novaya Zemlya, Russian Arctic. Journal of Glaciology 55(194), 960-972. doi: 10.3189/002214309790794940

Hewitt K (2007) Tributary glacier surges: an exceptional concentration at Panmah Glacier, Karakoram Himalaya. Journal of Glaciology 53(181), 181-188. doi: 10.3189/172756507782202829 
Jiskoot H and Juhlin DT (2009) Surge of a small East Greenland glacier, 2001-2007, suggests Svalbard-type surge mechanism. Journal of Glaciology 55(191), 567-570. doi: 10.3189/002214309788816605

Kamb B (1987) Glacier surge mechanism based on linked cavity configuration of the basal water conduit system. Journal of Geophysical Research 92(B9), 9083. doi: 10.1029/JB092iB09p09083

Kamb B and 7 others (1985) Glacier surge mechanism: 1982-1983 surge of variegated glacier, Alaska. Science (New York, N.Y.) 227, 469-479. doi: 10. 1126/science.227.4686.469

King O, Bhattacharya A and Bolch T (2021) The presence and influence of glacier surging around the Geladandong ice caps, North East Tibetan Plateau. Advances in Climate Change Research. doi: 10.1016/j.accre.2021.05.001

Kochtitzky W and 6 others (2019) Terminus advance, kinematics and mass redistribution during eight surges of Donjek Glacier, St. Elias Range, Canada, 1935 to 2016. Journal of Glaciology 65(252), 565-579. doi: 10. 1017/jog.2019.34

Leprince S, Barbot S, Ayoub F and Avouac J-P (2007) Automatic and precise orthorectification, coregistration, and subpixel correlation of satellite images, application to ground deformation measurements. IEEE Transactions on Geoscience and Remote Sensing 45(6), 1529-1558. doi: 10.1109/tgrs.2006.888937

Liu Q and 6 others (2020) Interannual flow dynamics driven by frontal retreat of a lake-terminating glacier in the Chinese Central Himalaya. Earth and Planetary Science Letters 546, 116450. doi: 10.1016/j.epsl.2020.116450

Lovell AM, Carr JR and Stokes CR (2018) Topographic controls on the surging behaviour of Sabche Glacier, Nepal (1967 to 2017). Remote Sensing of Environment 210, 434-443. doi: 10.1016/j.rse.2018.03.036

Murray T, Dowdeswell JA, Drewry DJ and Frearson I (1998) Geometric evolution and ice dynamics during a surge of Bakaninbreen, Svalbard. Journal of Glaciology 44(147), 263-272. doi: 10.3189/s0022143000002604

Murray T, Strozzi T, Luckman A, Jiskoot H and Christakos P (2003) Is there a single surge mechanism? Contrasts in dynamics between glacier surges in Svalbard and other regions. Journal of Geophysical Research: Solid Earth 108(B5), 2237. doi: 10.1029/2002jb001906

Paul F (2020) A 60-year chronology of glacier surges in the central Karakoram from the analysis of satellite image time-series. Geomorphology 352, 106993. doi: 10.1016/j.geomorph.2019.106993

Paul F, Strozzi T, Schellenberger T and Kääb A (2017) The 2015 surge of Hispar Glacier in the Karakoram. Remote Sensing 9(9), 888. doi: 10.3390/ rs9090888

Pitte P and 7 others (2016) Geometric evolution of the Horcones Inferior Glacier (Mount Aconcagua, Central Andes) during the 2002-2006 surge. Journal of Geophysical Research: Earth Surface 121(1), 111-127. doi: 10. 1002/2015jf003522
Pu J (1994) Glacier Inventory of China VII the Yangtze River Drainage Basin. Lanzhou, China: Gansu Culture Press.

Rashid I, Majeed U, Jan A and Glasser NF (2020) The January 2018 to September 2019 surge of Shisper Glacier, Pakistan, detected from remote sensing observations. Geomorphology 351, 106957. doi: 10.1016/j.geomorph.2019.106957

Raymond C, Johannesson T, Pfeffer T and Sharp M (1987) Propagation of a glacier surge into stagnant ice. Journal of Geophysical Research 92(B9), 9037. doi: 10.1029/JB092iB09p09037

Scherler D, Leprince S and Strecker M (2008) Glacier-surface velocities in alpine terrain from optical satellite imagery - accuracy improvement and quality assessment. Remote Sensing of Environment 112(10), 3806-3819. doi: 10.1016/j.rse.2008.05.018

Sevestre H and Benn DI (2015) Climatic and geometric controls on the global distribution of surge-type glaciers: implications for a unifying model of surging. Journal of Glaciology 61(228), 646-662. doi: 10.3189/2015JoG14J136

Shangguan D and 6 others (2016) Characterizing the May 2015 Karayaylak Glacier surge in the eastern Pamir Plateau using remote sensing. Journal of Glaciology 62(235), 944-953. doi: 10.1017/jog.2016.81

Sund M, Eiken T, Hagen JO and Kääb A (2009) Svalbard surge dynamics derived from geometric changes. Annals of Glaciology 50(52), 50-60. doi: $10.3189 / 172756402781817491$

Tian L and 9 others (2016) Two glaciers collapse in western Tibet. Journal of Glaciology 63(237), 194-197. doi: 10.1017/jog.2016.122

Wei J and 6 others (2014) Surface-area changes of glaciers in the Tibetan Plateau interior area since the 1970s using recent Landsat images and historical maps. Annals of Glaciology 55(66), 213-222. doi: 10.3189/ 2014AoG66A038

Xu J, Shangguan D and Wang J (2018) Three-dimensional glacier changes in Geladandong Peak Region in the Central Tibetan Plateau. Water 10(12), 1749. doi: 10.3390/w10121749

Yan J, Lv M, Ruan Z, Yan S and Liu G (2019) Evolution of surge-type glaciers in the Yangtze river headwater using multi-source remote sensing data. Remote Sensing 11(24), 2991. doi: 10.3390/rs11242991

Yasuda T and Furuya M (2013) Short-term glacier velocity changes at West Kunlun Shan, Northwest Tibet, detected by synthetic aperture radar data. Remote Sensing of Environment 128, 87-106. doi: 10.1016/j.rse.2012.09.021

Yasuda T and Furuya M (2015) Dynamics of surge-type glaciers in West Kunlun Shan, Northwestern Tibet. Journal of Geophysical Research: Earth Surface 120(11), 2393-2405. doi: 10.1002/2015jf003511

Yde JC and Paasche $\emptyset$ (2010) Reconstructing climate change: not all glaciers suitable. Eos Transactions AGU 91(21), 189-190. doi: 10.1029/ 2010EO210001 